\title{
Trade Policy versus Trade Facilitation: An Application Using 'Good Old’ OLS
}

\author{
Laura Márquez-Ramos \\ Universitat Jaume I, Castellón \\ Inmaculada Martínez-Zarzoso \\ Georg-August Universitaet Goettingen and Universitat Jaume I, Castellón \\ Celestino Suárez-Burguet \\ Universitat Jaume I, Castellón
}

\begin{abstract}
Trade policy barriers are only one element of overall trade costs. Among these, and due to the decrease in the influence of tariff barriers on trade over time, institutional barriers might increase in relative importance and become a key obstacle to the movements of goods across countries. This paper quantifies and compares the impact that a number of trade facilitation and trade policy barriers have on bilateral trade flows. A theoretically justified gravity model of trade is estimated by using the methodology proposed in Baier and Bergstrand (Bonus vetus OLS: A simple method for approximating international trade-cost effects using the gravity equation, 2009) for a cross-section of countries in the year 2000. Results indicate that institutional trade barriers have a greater impact on trade flows than tariff barriers. According to these findings, trade policy negotiation efforts should focus on facilitating trade processes and should be at the forefront of multilateral negotiations.
\end{abstract}

Special Issue on Trade Facilitation, Transport Costs and Logistics: A New Challenge for European Competitiveness

JEL F14

Keywords Tariff barriers; trade facilitation; sectoral trade

Correspondence Laura Márquez-Ramos, Department of Economics and Institute of International Economics, Universitat Jaume I, Castellón, Spain; e-mail: lmarquez@eco.uji.es

Citation Laura Márquez-Ramos, Inmaculada Martínez-Zarzoso, and Celestino Suárez-Burguet (2012). Trade Policy versus Trade Facilitation: An Application Using 'Good Old' OLS. Economics: The Open-Access, OpenAssessment E-Journal, Vol. 6, 2012-11. http://dx.doi.org/10.5018/economics-ejournal.ja.2012-11

(c) Author(s) 2012. Licensed under a Creative Commons License - Attribution-NonCommercial 2.0 Germany 
conomics: The Open-Access, Open-Assessment E-Journal

\section{$1 \quad$ Introduction}

In the last decades, trends towards geographical regionalisation and globalisation have led to a decrease in the influence of tariff barriers on trade. Indeed, in 1987, the overall annual average applied tariff rate (expressed in non-weighted terms) was 25\%, whereas in 2007 this figure was only 9\%. ${ }^{1}$ As a consequence, other trade cost components, such as transport costs and information costs, have gained importance as determinants of trade patterns worldwide. Indeed, a broader concept named "trade facilitation" is of growing interest in the trade policy debate and has been explicitly included in the Doha Development Agenda.

While the role of tariffs in trade has a long tradition (see e.g. Kreinin, 1961; Harrigan, 1993), as is the case with technological innovation (see e.g. Vernon, 1970; Soete, 1987; Freund and Weinhold, 2004; Fink, Mattoo and Neagu, 2005; Márquez-Ramos and Martínez-Zarzoso, 2010), only recently have a number of studies examined the importance of trade facilitation (Wilson, Mann and Otsuki, 2005; Djankov, Freund and Pham, 2006; Martínez-Zarzoso and Márquez-Ramos, 2008). In earlier studies, the usual approach was to focus on only one of the abovementioned trade determinants, instead of considering simultaneously the effect of the different components of trade costs. More recently, a few studies have considered different components of trade costs in one sole study. Examples are Baier and Bergstrand (2001), who explained the growth of world trade with transport costs, tariffs and income variables and Anderson and van Wincoop (2004), who specifically studied the different components of trade cost and their trade effects and presented an extensive review of the empirical literature.

From a methodological point of view, a growing number of studies use the gravity model of trade as a general framework to estimate the determinants of bilateral trade flows. However, only the most recent research solves some of the estimation problems related to the correct specification of the so-called multilateral resistance terms (MR). Anderson and van Wincoop (2003) show that it is not just bilateral trade costs, but those costs relative to multilateral trade that are relevant for predicting bilateral trade. Omitting controls for MR can lead to biased coefficient estimates. More importantly, it can lead to grossly misleading comparative static estimates of the impact of trade barriers on trade. Based upon

1 See Figure A.1 in the Appendix I. 
the model of Anderson and van Wincoop (2003), Baier and Bergstrand (2009) proposed a first-order log-linear approximation method that introduces theoretically-motivated exogenous MR terms and generates comparative statics.

This paper aims to contribute to the existing literature on four fronts. First, it aims to quantify and compare the effect of policy and institutional trade barriers on international trade flows. We consider the role of tariffs to measure policy trade barriers, whereas internal transport costs, time required to cross borders and the number of documents required for trade, together with information technology are considered to measure trade facilitation procedures. Secondly, the methodology developed by Baier and Bergstrand (2009) is used for constructing MR terms for all bilateral variables, in the context of the Anderson and van Wincoop (2003) structural gravity model. The advantage of this method over the traditional loglinear OLS approach is that it is based on a theoretically grounded gravity model. Thirdly, as there are clear economic differences between developed and developing countries leading to disparities in the impact that the determinants of bilateral trade flows have on trade, the model will be estimated separately for each exporter. Finally, the model is also estimated for different sectors as both trade policy and institutional barriers are expected to have a differential effect on the exports of different sectors. To our knowledge, this is the first paper that quantifies the relative role of trade policy and institutional trade barriers by using a theoretically well-specified gravity model.

The main results can be summarised as follows. Firstly, a reduction in the number of days and the number of documents needed for trade promotes international trade to a greater extent than equivalent reductions in tariff barriers. Secondly, the former effect is comparable to the effect of distance on trade. Finally, information technology also plays an important role in promoting trade.

The paper is organised as follows. A review of the literature on trade facilitation is provided in Section 2, along with an outline of the methodology used in this paper. Section 3 presents the data, sources and variables used, together with a detailed description of how the trade facilitation and tariff data were gathered. Section 4 specifies the model and details the main results. Section 5 performs the sensitivity analysis. Finally, Section 6 offers some concluding remarks and policy implications. 
conomics: The Open-Access, Open-Assessment E-Journal

\section{$2 \quad$ Literature Review}

In this section we mainly review the recent literature related to trade facilitation in a very broad sense, including information technology as one of the factors that facilitate trade, and hence, affects the volume of trade. But, as we also consider the effect of tariffs, we believe it is worth briefly referring to the literature on the effects of trade policy barriers on imports. Two different approaches can be distinguished in the literature. The first methodology uses the gravity model to identify the impact of various trade barriers on bilateral trade flows (Wilson et al. 2005). The second adopts instead a synthetic measure of ad valorem transportation costs which can be compared to average tariffs (Harrigan, 1993; Hummels, 2007). This paper is in the first branch, although it complements and reinforces recent work in the second branch (Pomfret and Sourdin, 2010).

In relation to tariffs, Harrigan (1993) is probably the paper most related to our investigation. The author develops a monopolistic competition model to evaluate the effect of trade barriers on OECD imports. In his model, transport costs are also included as a determinant of trade and trade policy barriers are divided into tariffs and non-tariff barriers (NTBs). In his empirical evaluation of the theoretical model, estimated for a cross-section of 13 OECD countries and 28 product categories using data for 1983, Harrigan concludes that estimated transport costs and average tariffs had a marked negative effect on imports, although the level of tariffs was generally low. In contrast, NTBs had a small or imperceptible effect on gross imports. In a more recent paper, Chen (2004) analyses the effect of non-tariff barriers and, in particular, technical barriers on the volume of exports in the context of the border effect. This author finds that technical barriers together with product-specific information increase border effects.

As regards trade facilitation, this issue is clearly gaining interest in the trade policy debate, as shown by its inclusion in the Doha Development Agenda. However, the measurement and quantification of the potential benefits of trade facilitation have only recently been investigated and the approaches used are far from uniform in terms of the definition of trade facilitation and the empirical approach used.

In relation to the definition, Wilson et al. $(2003,2005)$ considered a broad definition of trade facilitation and quantified the impact of four different measures (port efficiency, customs environment, regulatory environment and e-business 
usage). As an alternative, Engman (2005) used the WTO definition of trade facilitation (the simplification and harmonisation of international trade procedures) by paying attention only to what happens around the border. Other authors ${ }^{2}$ focused instead on the effects of single measures of trade facilitation (information technology, port efficiency, institution quality).

Two main modelling approaches have been used. On the one hand, several papers use the gravity model of trade augmented with "trade facilitation" variables. In this line, Wilson et al. (2003, 2005) estimated a gravity model of trade augmented with the above-mentioned trade-facilitation variables for a group of countries in the Asia-Pacific region and for a sample of 75 countries. In addition, Soloaga, Wilson and Mejía (2006) used a similar methodology and data, but focused on Mexican competitiveness. In a more general setting, Djankov et al. (2006) used the World Bank's Doing Business Database, as we do in this paper, but focused only on the effects of time delays in the exporting country, whereas Nordas, Pinali and Grosso (2006) concentrated on how time delays affect the probability to export and export volumes for imports from Japan, Australia and the United Kingdom. Persson (2007) studied the effect of time delays and transaction costs on trade flows using a sample selection approach and focusing on the specific effects for each of the six groups of ACP countries negotiating Economic Partnership agreements with the EU. Finally, Martínez-Zarzoso and MárquezRamos (2008) analyse the effect of trade facilitation on trade volumes at a disaggregated level. They focus on the simplification of "at the border procedures", which includes the number of documents and amount of time involved in border crossings, as well as the transaction costs incurred. Their results support multilateral initiatives that encourage countries to assess and improve their trade facilitation needs and priorities.

On the other hand, several institutions and authors (UNCTAD, 2001; OECD, 2003; Dennis, 2006; Decreux and Fontagne, 2006) used a computable general equilibrium model to estimate the effect of a composite index of trade facilitation on trade flows.

2 See Wilson, Mann and Otsuki (2003, 2005) for a more detailed review of earlier work on single measures of trade facilitation. 
conomics: The Open-Access, Open-Assessment E-Journal

Although several data sets and estimation methods have been utilised within the context of these two approaches, the results reveal significant and positive effects on trade flows in most cases.

This paper mainly differs from the existing literature in that it estimates the effectiveness of several trade facilitation measures together with the effectiveness of trade liberalisation, by including different measures of trade facilitation for exporter and importer countries and improving the methodological approach.

\section{Data, Sources and Variables}

Bilateral trade data by commodity were obtained from Feenstra et al. (2005). The level of disaggregation chosen was the 4-digit Standard International Trade Classification (SITC). The sample of countries comprised 13 exporters and 167 importers in the year 2000 (Table A.1, Appendix I). The 13 exporters were chosen to have a representative sample of the world economy in accordance to the classification matrix constructed in Martínez-Zarzoso and Márquez-Ramos (2008). The sectors analysed include 146 industries with homogeneous goods, 349 with reference-priced goods and 694 with differentiated goods.

The databases used to construct the explanatory variables for the regression analysis are the World Development Indicators (World Bank, 2005) for income ${ }^{3}$ and the Doing Business (World Bank, 2006) database for trade facilitation variables. This database was recently created by the World Bank and compiles procedural requirements for exporting and importing a standardised cargo of goods (see Appendix II). Trade facilitation data refer to 2004. Distance between capitals is taken from CEPII. ${ }^{4}$ As in Márquez-Ramos and Martínez-Zarzoso (2010), technological innovation is proxied using the Technological Achievement Index (TAI) computed by UNDP (2001).

\footnotetext{
3 We are aware of the fact that sectoral production could be a better proxy for exporter supply capacity when using sectoral data. Unfortunately, these data are not available for all the exporter countries analysed.

4 The dist_cepii file was taken from http://www.cepii.fr/anglaisgraph/bdd/distances.htm. Simple distances are calculated following the great circle formula, which uses the latitudes and longitudes of the most important cities or agglomerations (in terms of population).
} 
Tariff data come from the Trade Analysis Information System (TRAINS) and were extracted using the World Integrated Trade Solution (WITS). The tariffs faced by each of the 13 exporting countries were collected using the importing countries as reporting countries. We obtained tariffs weighted by their corresponding trade values at one digit SITC level in the year 2000. TRAINS presents three types of tariff for each product: bound rate, preferential and MostFavoured Nation tariffs (MFN). Bound tariffs are specific commitments made by individual WTO members. The bound rate is the maximum MFN tariff level for a given product line. When WTO members negotiate tariff levels, they agree the bound tariff rates, but these are not necessarily the same rates that a WTO member applies to other WTO members' products. ${ }^{5}$ The preferential rate is the lowest. Under a preferential trade agreement, one country imposes lower tariffs on another country's products than their MFN rate. Exporting countries may therefore have access to several different preference programmes from a given importing partner and for a given product. MFN tariffs are the rate countries promise to impose on imports from other members of the World Trade Organisation, unless the country is part of a preferential trade agreement.

WITS uses the concept of effectively applied tariffs, defined as the lowest tariff granted by an importer to an exporter for a particular product. The rates used in this paper are the weighted average of effectively applied tariffs for each country importing each product from the 13 exporters in the sample. Table 1 shows the weighted average tariffs imposed on imports from the 13-country sample to all importing countries in the year 2000 for the different sections of the Standard International Trade Classification (SITC, revision 2).

Overall, protection is greater on "sensitive" products ${ }^{6}$ such as food and live animals, beverages and tobacco and animal and vegetable oils, fats and waxes. Finally, the first half of Table 2 shows summary statistics of the variables used in the empirical application (except dummy variables) and the second half shows their simple correlations after the linear transformation that is explained in the next section.

5 Countries can break a commitment (i.e. raise a tariff above the bound rate), but only with difficulty. To do so they have to negotiate with the countries most involved and this could result in compensation for trading partners' loss of trade.

6 We refer to "sensitive" products as those products which are susceptible to competition from imports from other country suppliers. 


\section{Economics: The Open-Access, Open-Assessment E-Journal}

Table 1: Average Effectively Applied Tariffs (Expressed in Weighted Terms) Imposed on Imports from the 13-Country Sample by all Countries in the Year 2000

\begin{tabular}{|c|c|c|c|c|c|c|c|c|}
\hline Prod. & Product Name & $\begin{array}{l}\text { South } \\
\text { Africa }\end{array}$ & Australia & Bolivia & Brazil & Chile & China & $\begin{array}{l}\text { Czech } \\
\text { Republic }\end{array}$ \\
\hline 0 & Food and live animals & 9.92 & 18.41 & 12.92 & 9.30 & 7.20 & 7.33 & 17.61 \\
\hline 1 & Beverages and tobacco & 12.90 & 6.93 & 15.23 & 25.30 & 7.21 & 5.04 & 34.26 \\
\hline 3 & Mineral fuels, lubricants and related materials & 3.38 & 1.47 & 0.66 & 1.56 & 6.61 & 2.61 & 1.40 \\
\hline 4 & Animal and vegetable oils, fats and waxes & 10.42 & 11.27 & 19.54 & 17.19 & 9.66 & 1.97 & 17.06 \\
\hline 5 & Chemicals and related products, n.e.s. & 6.04 & 3.56 & 7.07 & 3.69 & 5.95 & 4.68 & 4.36 \\
\hline 9 & Commodities and transactions, n.e.s. & 14.72 & 1.54 & 0.00 & 2.86 & 0.68 & 7.30 & 10.90 \\
\hline Prod. & Product Name & Germany & Ghana & Japan & Spain & $\begin{array}{c}\text { United } \\
\text { UK }\end{array}$ & $\begin{array}{c}\text { United } \\
\text { States }\end{array}$ & \\
\hline 0 & Food and live animals & 14.16 & 1.65 & 10.46 & 12.19 & 13.75 & 18.70 & \\
\hline 1 & Beverages and tobacco & 16.25 & 7.45 & 21.31 & 14.70 & 23.83 & 30.22 & \\
\hline 7 & Machinery and transport equipment & 5.54 & 1.92 & 5.27 & 8.23 & 3.71 & 4.07 & \\
\hline 8 & Miscellaneous manufactured articles & 4.07 & 3.56 & 4.29 & 10.05 & 4.30 & 5.99 & \\
\hline 9 & Commodities and transactions, n.e.s. & 3.23 & 0.00 & 0.23 & 4.44 & 11.42 & 1.32 & \\
\hline
\end{tabular}

Source: WITS (2008) and authors' calculations. 


\section{Economics: The Open-Access, Open-Assessment E-Journal}

Table 2: Summary Statistics and Correlations

\begin{tabular}{|c|c|c|c|c|c|c|c|c|}
\hline \multicolumn{9}{|l|}{ Summary Statistics } \\
\hline Exports (thousands of US\$) & 226029 & 25100.1 & 296128 & 0 & $4.31 \mathrm{E}+07$ & & & \\
\hline Importer Income (US\$) & 196430 & $7.09 \mathrm{E}+11$ & $1.61 \mathrm{E}+12$ & $4.95 \mathrm{E}+08$ & $9.63 \mathrm{E}+12$ & & & \\
\hline Distance (km) & 207313 & 6935.02 & 4977.62 & 173.524 & 19586.2 & & & \\
\hline Ad-valorem tariff (\%) & 195365 & 8.72824 & 6.49074 & 0 & 119 & & & \\
\hline Ad-valorem weighted tariff (\%) & 210912 & 7.49892 & 11.80166 & 0 & 928.04 & & & \\
\hline Time to export (days) & 226029 & 12.5176 & 6.07162 & 6 & 31 & & & \\
\hline Time to import (days) & 199841 & 22.54901 & 16.1429 & 3 & 139 & & & \\
\hline Documents to export (number) & 226029 & 5.1739 & 0.96657 & 4 & 12 & & & \\
\hline Documents to import (number) & 199841 & 8.142495 & 3.61971 & 2 & 20 & & & \\
\hline $\begin{array}{l}\text { Transport costs to export } \\
\text { (US\$ per container) }\end{array}$ & 226029 & 712.212 & 188.29 & 335 & 1110 & & & \\
\hline Exports & 1.000 & & & & & & & \\
\hline Income & 0.370 & 1.000 & & & & & & \\
\hline Distance & -0.244 & -0.048 & 1.000 & & & & & \\
\hline Tariffs & -0.148 & 0.041 & 0.548 & 1.000 & & & & \\
\hline TAI & 0.268 & 0.390 & 0.025 & 0.039 & 1.000 & & & \\
\hline Time & -0.242 & -0.270 & -0.006 & -0.014 & -0.726 & 1.000 & & \\
\hline Transport Costs & -0.097 & -0.222 & 0.038 & -0.015 & -0.090 & 0.298 & 1.000 & \\
\hline Documents & -0.157 & -0.101 & -0.054 & 0.008 & -0.506 & 0.715 & 0.129 & 1.000 \\
\hline
\end{tabular}

www.economics-ejournal.org 
conomics: The Open-Access, Open-Assessment E-Journal

\section{$4 \quad$ Empirical Analysis}

The empirical analysis is based on the gravity model of trade, which is widely recognised for its impressive goodness of fit when applied to bilateral trade flows. Indeed, some authors have referred to this model as the "workhorse" of empirical trade studies (Eichengreen and Irwin, 1998; Cheng and Wall, 2005). In the context of the gravity model, Anderson and van Wincoop (2003) emphasize the dependence of trade on a bilateral and multilateral resistance factor. These authors refer to price indices as "multilateral resistance" variables that depend on all bilateral resistances, including those that do not directly involve the exporting country.

The theoretical background for our study is provided by the model in Baier and Bergstrand (2009). This model is a generalisation of previous work on the gravity equation, in which special attention is given to modelling the so-called multilateral resistance terms. Baier and Bergstrand (2009) demonstrate that a first-order loglinear Taylor series expansion of the nonlinear system of price equations provides an alternative OLS log-linear specification that introduces theoretically motivated MR. This methodology has two basic advantages over the other approaches recently proposed to estimate a "theoretically motivated" gravity equation. Firstly, it is simpler than the custom nonlinear least squares (CNLS) program proposed by Anderson and van Wincoop (2003), which has scarcely been applied by empirical researchers. Secondly, it enables researchers to estimate the comparative static effects of trade costs. The most commonly applied approach to estimate potentially unbiased gravity equation coefficients since Anderson and van Wincoop (2003) is to use region-specific fixed effects, as already suggested by the authors and by Feenstra (2004). Although this method is very simple and avoids the measurement error associated with measuring regions' "internal distances" (as in CNLS), it does not allow direct estimation of the comparative static effects of trade costs. However, an indirect estimation of those effects can be obtained after estimating the parameters with fixed effects. In this case, the estimation stage (which can include fixed effects) has to be distinguished from the counterfactual analysis. The parameter estimates from the fixed effects specification are used in a counterfactual analysis based on the underlying theoretical structure of the model. Moreover, the Anderson and van Wincoop (2003) approach is only valid in a 
world with symmetrical bilateral trade costs $\left(t_{i j}=t_{j i}\right),{ }^{7}$ whereas the MR approximation terms also work under asymmetrical bilateral trade $\operatorname{costs}^{8}$ and, in the real world, many trade costs are bilaterally asymmetric, such as tariff rates and transport costs.

Baier and Bergstrand (2009) suggest applying a first-order Taylor expansion to the explanatory variables and then using OLS to estimate the gravity model specified with the transformed variables. It could be argued that a simple methodology that allows for counterfactual analysis is a fixed effects specification as proposed by Feenstra (2004). Yet Feenstra (2004)'s gravity specification has some drawbacks in the context of this investigation. Indeed, the use of country dummies or country-and-time dummies to control for the so-called multilateral resistance terms interferes with the inclusion of trade facilitation variables, such as the number of required documents to trade and the number of required days to trade in different countries, which do not usually change much over time (Martínez-Zarzoso and Márquez-Ramos, 2008). Indeed, the use of country fixed effects controls for all country-specific influences and does not permit estimating the impact of a change in trade frictions that are country specific. With regard to this last point, if we estimate the impact of tariffs on bilateral trade with the use of country-fixed effects, and then we control for multilateral trade resistance, the estimate tells us how much tariff barriers deter bilateral trade over the sample, but we would not be able to answer a question such as what is the impact of reducing the number of days required to trade on exports of different countries. To do that, we would need to allow for the resulting changes in multilateral trade resistance in every country, and then changes in the country-fixed effects should be admitted. Baier and Bergstrand (2009) methodology allows both to analyse the impact of exogenous changes and to engage in comparative static exercises. The focus in this paper is on estimation (not in comparative statics) and therefore simple average

7 Anderson and van Wincoop (2003) methodology can also be adapted to account for asymmetries (see for example, Anderson and Yotov, 2010; Bergstrand, Egger and Larch, 2011). Since Baier and Bergstrand (2009)'s approximation method is derived allowing for bilaterally asymmetric trade costs, this approach may generate lower biases in comparative statistics than the Anderson and van Wincoop (2003) method when trade costs are indeed asymmetric, as the latter method only addresses "average” border effects.

8 See Addendum to "Bonus Vetus OLS” (B-B, 2007) in:

http://www.nd.edu/ jbergstr/working_papers.html 
conomics: The Open-Access, Open-Assessment E-Journal

weights $(1 / \mathrm{N})$ are used in the MR construction, instead of the GDP shares used as weights in Baier and Bergstrand (2009). By using this methodology and following Melitz (2008), the bilateral independent variables are transformed as follows:

$$
\left(x_{i j}\right)_{P_{i} P_{j}}=\frac{1}{N_{r}} \sum_{r=1}^{N_{r}} x_{i r}+\frac{1}{N_{m}} \sum_{m=1}^{N_{m}} x_{m j}-\frac{1}{N_{r}} \frac{1}{N_{m}} \sum_{r=1}^{N_{r}} \sum_{m=1}^{N_{m}} x_{r m}
$$

where $r$ is an index of the country partners of $i$ and $m$ is an index of the country partners of $\mathrm{j}$. Equation (1) refers to variables with bilateral variability (e.g. distance) ${ }^{9}$ and both bilateral and sectoral variability (tariffs), which are a proxy for bilateral trade costs. The first term on the RHS is the simple average of the gross trade costs facing exporter i across all importers $r$, whereas the second term on the RHS is the simple average of the gross trade costs facing importer $\mathrm{j}$ across all exporters $\mathrm{m}$.

In order to quantify and compare the effect of trade barriers (tariffs and trade facilitation measures) on sectoral trade, a gravity equation is specified and estimated for disaggregated data. Equation (1) underlies the construction of the terms with the $P_{i} P_{j}$ subscripts that are associated with coefficients $\alpha 2-\alpha 13$ in Equation (2). In addition to income, distance, tariffs and trade facilitation variables, integration dummies are added in order to analyse the impact of trade agreements on international trade. A number of dummies representing geographical and cultural characteristics are also added. The estimated equation is:

$$
\begin{aligned}
& \ln X_{i j k}=\alpha_{0}+\alpha_{1} \ln \left(Y_{i} Y_{j}\right)+\alpha_{2}\left(\ln \text { Dist }_{i j}-\ln \text { Dist }_{P_{i} P_{j}}\right)+\alpha_{3}\left(\ln \text { Tariffs }_{i j k}-\ln \text { Tariffs }_{P_{i} P_{j}}\right) \\
& +\alpha_{4}\left(C A N_{i j}-C A N_{P_{i} P_{j}}\right)+\alpha_{5}\left(M E R C_{i j}-M E R C_{P_{i} P_{j}}\right)+\alpha_{6}\left(E U_{i j}-E U_{P_{i} P_{j}}\right) \\
& +\alpha_{7}\left(E M U_{i j}-E M U_{P_{i} P_{j}}\right)+\alpha_{8}\left(E C O W A S_{i j}-E C O W A S_{P_{i} P_{j}}\right) \\
& +\alpha_{9}\left(\operatorname{CEFTA}_{i j}-\operatorname{CEFTA}_{P_{i} P_{j}}\right)+\alpha_{10}\left(\operatorname{NAFTA}_{i j}-\operatorname{NAFTA}_{P_{i} P_{j}}\right)+\alpha_{11}\left(\operatorname{Col}_{i j}-\operatorname{Col}_{P_{i} P_{j}}\right) \\
& +\alpha_{12}\left(\text { Lang }_{i j}-\text { Lang }_{P_{i} P_{j}}\right)+\alpha_{13}\left(\text { Contig }_{i j}-\text { Contig }_{P_{i} P_{j}}\right)+\alpha_{14} \ln \left(E T_{i} E T_{j}\right)+\varepsilon_{i j k}
\end{aligned}
$$

where ln denotes natural logarithms. $X_{\mathrm{ijk}}$ denotes the value of exports of commodity k from country i to country $j$; $Y_{i}$ and $Y_{j}$ are incomes in the origin and destination market respectively; Dist $t_{\mathrm{ij}}$ is the geographical great circle distance in kilometres between the most important cities (in terms of population) of countries $i$

9 Note that the bilateral distances (and tariffs) have to be logged before doing the MR transformation. 
and $\mathrm{j}$. Tariff $\mathrm{ijk}_{\mathrm{j}}$ is the weighted average effectively applied tariff for each country importing each commodity from the 13 exporters. Martínez-Zarzoso and MárquezRamos (2008) used effectively applied rates in sector $\mathrm{k}$ and obtained the unexpected result of a positive sign for the tariff variable in their regressions. Hence, in the present paper, we take the construction of a proper tariff measure a step further. In order to do so, the rates used in this paper are the weighted average effectively applied tariffs for each country importing each product from each of the 13 exporters in the sample at 1-digit level (SITC classification). By doing so, we expect to capture the variability of policy barriers by exporter, by importer and by sector when estimating trade regressions. CAN is a dummy that takes a value of 1 when both exporting and importing countries are Andean Community members, zero otherwise; MERC is a dummy that takes a value of 1 when both exporting and importing countries belong to Mercosur and EU takes a value of 1 when countries are members of the European Union. Additionally, EMU takes a value of 1 when countries are members of the Economic and Monetary Union; ECOWAS takes a value of 1 when countries are members of the Economic Community of West African States; CEFTA takes a value of 1 when countries are members of the Central European Free Trade Agreement, and NAFTA takes a value of 1 when countries are members of the North American Free Trade Area. Col is a dummy that takes the value of 1 when trading partners have had a colonial link at any time; Lang is a dummy for countries sharing a common official language. Finally, Contig is a dummy that indicates whether the trading partners are contiguous. ET $_{\mathrm{i}}$ and $\mathrm{ET}_{\mathrm{j}}$ are easy-to-trade variables (technological innovation, internal transport costs, time and the number of documents required to trade) for the exporting and importing country respectively. Technological innovation is measured as the product of the Technological Achievement Index (TAI) of countries i and j, internal transport costs are measured as the product of the fees levied on a 20-foot container in US dollars in countries $\mathrm{i}$ and $\mathrm{j}$. All the fees associated with completing the procedures to export or import goods are included. Documentation (time) is measured as the product of the number of documents (days) required to trade in countries i and j. Easy-to-trade variables enter equation (2) as the log of the product of ET in the exporting and the importing countries to assume that the effect of the trade facilitation variables is of equal magnitude for both exporter and importer countries. Finally, $\varepsilon_{i j k}$ is the error term, which is assumed to be independently and identically distributed. 
Estimating equation (2) by OLS would yield identical coefficients to other estimates used to obtain unbiased gravity equation coefficients (fixed effects), 10 although as with any linear approximation, an approximation error is introduced: It would have a lower average absolute comparative-static error than the Anderson and van Wincoop (2003) method in the case of asymmetric bilateral trade costs $\left(t_{i j} \neq t_{j i}\right)$, which is a more realistic assumption when quantifying the impact that institutional and policy trade barriers have on bilateral trade flows.

First, a gravity equation is estimated by using fixed effects (see Table A.2, Appendix I). Although Baier and Bergstrand (2009) include $\ln \left(\mathrm{Y}_{\mathrm{i}}\right)$ and $\ln \left(\mathrm{Y}_{\mathrm{j}}\right)$ as two distinct regressors, we follow Melitz (2008), who include income as a single regressor in a similar context. Including $\ln \left(\mathrm{Y}_{\mathrm{i}} \mathrm{Y}_{\mathrm{j}}\right)$ restricts the income coefficients to be the same for $\mathrm{i}$ and $\mathrm{j}$, but the restriction does not affect other estimates in equation (2).

Second, since including GDPs as regressors may be problematic from an econometric point of view as they could be endogenously determined, ${ }^{11}$ the model is estimated by using importer- and exporter-specific fixed effects instead. ${ }^{12}$ The estimated equation is:

$$
\begin{aligned}
& \ln X_{i j k}=\delta_{i}+\lambda_{j}+\alpha_{0}+\alpha_{1} \ln \text { Dist }_{i j}+\alpha_{2} \ln \text { Tariffs }_{i j k}+\alpha_{3} \text { CAN }_{i j}+\alpha_{4} \text { MERC }_{i j} \\
& +\alpha_{5} E U_{i j}+\alpha_{6} \text { EMU }_{i j}+\alpha_{7} \text { ECOWAS }_{i j}+\alpha_{8} \text { CEFTA }_{i j}+\alpha_{9} \text { NAFTA }_{i j}+\alpha_{10} \text { Col }_{i j} \\
& +\alpha_{11} \text { Lang }_{i j}+\alpha_{12} \text { Contig }_{i j}+\alpha_{13} \ln \left(E T_{i} E T_{j}\right)+\varepsilon_{i j k}
\end{aligned}
$$

Table 3 shows the results obtained for the full sample following our preferred model - equation (2) - and Appendix I shows the results of estimating equation (3). With regard to tariffs and trade facilitation, similar conclusions are derived in

\footnotetext{
10 Actually, the Baier and Bergstrand (2009) methodology is numerically identical to fixed effects estimation in a balanced sample, i.e. one that has the same importers and exporters and includes the $\mathrm{x}_{\mathrm{ii}}$-observations. But the CNLS is not. Coefficients will in general not be identical between CNLS and fixed effects.

11 This follows from the methodology of Anderson and van Wincoop (2003), according to which changes in GDPs capture general equilibrium effects. The endogeneity of income is taken into account in Cyrus (2002). This author considers the possible problem of income's endogeneity in the gravity model of bilateral trade by using instrumental variables. The author finds that instrumenting for income barely affects the effect of income and other gravity variables on trade.
}

12 We are grateful to an anonymous reader for this suggestion. 
both estimations. Note that due to the complementarity of the ET variables considered, models 1-4 (in Table 3) include each trade facilitation variable separately, namely technological innovation, transport costs, number of days and number of documents required to trade, respectively. In order to improve the measure of ET, we also computed an average ET that is calculated as the simple average of the variables: $\sum_{m=1}^{3} \ln \left(x_{i m} x_{j m}\right) / 3$, where $x$ denotes time, internal transport costs and number of documents. ${ }^{13}$ The results obtained when including this variable are shown in Model 5 (last column of Table 3).

The estimated coefficients indicate that income variables have the expected positive effect on trade, whereas distance influences trade negatively. The OLS results also show that dummy variables included in the regression are significant and present the expected positive sign, with the exception ECOWAS, which has also been found to be significant and negative signed in previous research (see Martínez-Zarzoso and Márquez-Ramos, 2008). With respect to the variables of interest, tariff barriers record a negative and significant coefficient, as do internal transport costs, time to trade and number of documents, although the coefficients obtained for the trade facilitation variables are higher in magnitude. The coefficient of technological innovation is positive and significant, indicating that improving service infrastructure fosters international trade. The trade deterrent effect is greater for variables related to bureaucratic procedures and waiting time at the border than for internal transport costs.

Similar conclusions are found in the estimates with exporter and importer fixed effects (see Table A.2). A Wald test is then applied, confirming that the difference in the coefficients of tariff and trade facilitation variables is, in turn, statistically significant.

13 The expected sign of trade facilitation variables differs. Technological innovation is expected to have a positive effect on trade, whereas documents, time and internal transport costs are expected to have a negative effect. Therefore, technological innovation is not considered to calculate the average variable. 
Cconomics: The Open-Access, Open-Assessment E-Journal

Table 3: The Effect of Policy and Institutional Trade Barriers

\begin{tabular}{|c|c|c|c|c|c|}
\hline & Model 1 & Model 2 & Model 3 & Model 4 & Model 5 \\
\hline Income & $\begin{array}{c}0.331^{* * *} \\
122.906\end{array}$ & $\begin{array}{c}0.368^{* * *} \\
171.391\end{array}$ & $\begin{array}{c}0.319 * * * \\
146.2\end{array}$ & $\begin{array}{c}0.348 * * * \\
164.712\end{array}$ & $\begin{array}{c}0.323^{* * * *} \\
146.751\end{array}$ \\
\hline Distance & $\begin{array}{c}-0.367 * * * \\
-45.591\end{array}$ & $\begin{array}{c}-0.339 * * * \\
-46.507\end{array}$ & $\begin{array}{c}-0.380 * * * \\
-52.518\end{array}$ & $\begin{array}{c}-0.391 * * * \\
-53.662\end{array}$ & $\begin{array}{c}-0.373^{* * * *} \\
-51.422\end{array}$ \\
\hline Tariffs & $\begin{array}{c}-0.024 * * * \\
-10.816\end{array}$ & $\begin{array}{c}-0.011^{* * *} \\
-5.335\end{array}$ & $\begin{array}{c}-0.021 * * * \\
-10.21\end{array}$ & $\begin{array}{c}-0.015^{* * *} \\
-7.219\end{array}$ & $\begin{array}{c}-0.018 * * * \\
-8.644\end{array}$ \\
\hline CAN & $\begin{array}{c}1.254^{* * *} \\
4.923\end{array}$ & $\begin{array}{c}1.316^{* * * *} \\
5.4\end{array}$ & $\begin{array}{c}1.328^{* * * *} \\
5.438\end{array}$ & $\begin{array}{c}1.373 * * * \\
5.675\end{array}$ & $\begin{array}{c}1.351^{* * *} \\
5.48\end{array}$ \\
\hline MERC & $\begin{array}{c}-0.131^{* *} \\
-2.134\end{array}$ & $\begin{array}{c}0.147^{* *} \\
2.445\end{array}$ & $\begin{array}{l}-0.034 \\
-0.572\end{array}$ & $\begin{array}{l}-0.007 \\
-0.117\end{array}$ & $\begin{array}{c}0 \\
-0.003\end{array}$ \\
\hline EU & $\begin{array}{c}0.158^{* * *} \\
4.239\end{array}$ & $\begin{array}{c}0.336 * * * \\
9.538\end{array}$ & $\begin{array}{c}0.144^{* * *} \\
4.109\end{array}$ & $\begin{array}{c}0.169 * * * \\
4.815\end{array}$ & $\begin{array}{c}0.176^{* * *} \\
5.007\end{array}$ \\
\hline EMU & $\begin{array}{c}0.142 * * * \\
4.738\end{array}$ & $\begin{array}{c}0.071^{* *} \\
2.435\end{array}$ & $\begin{array}{c}0.065^{* *} \\
2.273\end{array}$ & $\begin{array}{c}0.086 * * * \\
2.996\end{array}$ & $\begin{array}{c}0.074^{* * *} \\
2.588\end{array}$ \\
\hline ECOWAS & $\begin{array}{c}-26.647^{* * *} \\
-9.534\end{array}$ & $\begin{array}{c}-0.961 * * * \\
-3.501\end{array}$ & $\begin{array}{c}-0.958 * * * \\
-3.379\end{array}$ & $\begin{array}{c}-1.046^{* * *} \\
-3.788\end{array}$ & $\begin{array}{c}-0.981 * * * \\
-3.493\end{array}$ \\
\hline CEFTA & $\begin{array}{c}0.663^{* * *} \\
14.674\end{array}$ & $\begin{array}{c}0.570 * * * \\
13.099\end{array}$ & $\begin{array}{c}0.649 * * * \\
14.796\end{array}$ & $\begin{array}{c}0.538^{* * *} \\
12.19\end{array}$ & $\begin{array}{c}0.558^{* * *} \\
12.709\end{array}$ \\
\hline NAFTA & $\begin{array}{c}0.898^{* * *} \\
13.212\end{array}$ & $\begin{array}{c}1.098^{* * *} \\
16.425\end{array}$ & $\begin{array}{c}1.057 * * * \\
15.698\end{array}$ & $\begin{array}{c}1.047 * * * \\
15.594\end{array}$ & $\begin{array}{c}1.060^{* * *} \\
15.625\end{array}$ \\
\hline Colony & $\begin{array}{c}0.202 * * * \\
9.955\end{array}$ & $\begin{array}{c}0.166 * * * \\
8.829\end{array}$ & $\begin{array}{c}0.197 * * * \\
10.574\end{array}$ & $\begin{array}{c}0.189 * * * \\
10.123\end{array}$ & $\begin{array}{c}0.190^{* * *} \\
10.182\end{array}$ \\
\hline Language & $\begin{array}{c}0.180 * * * \\
9.787\end{array}$ & $\begin{array}{c}0.217^{* * *} \\
12.933\end{array}$ & $\begin{array}{c}0.155^{* * *} \\
9.459\end{array}$ & $\begin{array}{c}0.172 * * * \\
10.474\end{array}$ & $\begin{array}{c}0.174 * * * \\
10.528\end{array}$ \\
\hline Contiguity & $\begin{array}{c}0.537 * * * \\
22.072\end{array}$ & $\begin{array}{c}0.510^{* * *} \\
22.499\end{array}$ & $\begin{array}{c}0.435^{* * *} \\
19.933\end{array}$ & $\begin{array}{c}0.460 * * * \\
20.988\end{array}$ & $\begin{array}{c}0.466 * * * \\
21.164\end{array}$ \\
\hline TAI & $\begin{array}{c}0.538 * * * \\
63.644\end{array}$ & & & & \\
\hline Transport Costs & & $\begin{array}{c}-0.048 * * * \\
-6.823\end{array}$ & & & \\
\hline Time & & & $\begin{array}{c}-0.378 * * * \\
-78.974\end{array}$ & & \\
\hline Documents & & & & $\begin{array}{c}-0.500 * * * \\
-63.324\end{array}$ & \\
\hline ET_average & & & & & $\begin{array}{c}-0.556 * * * \\
-68.303\end{array}$ \\
\hline Constant Term & $\begin{array}{c}-10.002^{* * *} \\
-65.899\end{array}$ & $\begin{array}{c}-12.233^{* * *} \\
-72.56\end{array}$ & $\begin{array}{c}-8.234 * * * \\
-64.003\end{array}$ & $\begin{array}{c}-9.968 * * * \\
-80.859\end{array}$ & $\begin{array}{c}-6.302 * * * \\
-41.66\end{array}$ \\
\hline R-squared & 0.224 & 0.209 & 0.234 & 0.227 & 0.228 \\
\hline Number of observations & 149885 & 183420 & 183420 & 183420 & 183420 \\
\hline RMSE & 1.705479 & 1.684433 & 1.658351 & 1.665775 & 1.663984 \\
\hline
\end{tabular}

Notes: $* * * * *, *$ indicate significance at $1 \%, 5 \%$ and $10 \%$, respectively. The corresponding t-statistic is reported below each coefficient. The dependent variable is the natural logarithm of exports in value (thousands of \$US) of commodity k from country $\mathrm{i}$ to j. The estimation uses White's heteroskedasticity-consistent standard errors. Data is for the year 2000. 
As each variable is measured in different units, we calculate beta coefficients to be able to compare the magnitude of the effects in terms of standard deviations. The beta coefficients are shown in Table A.3 in the Appendix I. The highest beta coefficients are, in absolute terms, for income and a number of trade facilitation variables, especially time to trade, technological innovation and number of documents. Tariff barriers and internal transport costs record the lowest beta coefficients. These results indicate that trade facilitation variables play a more important role as determinants of trade patterns than tariff barriers. The beta coefficients are interpreted as follows: changing the time to trade by one standard deviation and holding constant the other explanatory variables would increase exports by 0.17 standard deviations, whereas the effect of a reduction in the average distance by one standard deviation would increase exports by 0.15 standard deviations. According to these estimates, a change in time to trade has a slightly greater relative effect on exports than a change in distance.

Finally, with respect to the goodness of fit of the model, the $\mathrm{R}$ squared indicates that the model is able to explain around twenty-two percent of the variability of sectoral exports. This low explanatory power, in comparison to the high explanatory power of the model when aggregated trade data are used, is common to other gravity model estimations using disaggregated data. ${ }^{14}$

\section{$5 \quad$ Sensitivity Analysis}

In this section we present estimates of the extended gravity model for different exporters and different types of goods to account for possible sources of heterogeneity in the sample. The level of protection for goods from developing countries face lower average weighted tariffs in developed countries than in developing countries; however, developing countries face higher tariffs in developed countries than those applied to developed countries trading among themselves (Table A.4). Average weighted tariffs equal to zero are more frequent among developed countries. Indeed, the second part of Table A.4 shows that the mean of the effectively applied weighted tariffs among developed countries is $4.5 \%$, while it is much higher when one (or both) of the trading partners is a

14 For a comparison, see Márquez-Ramos and Martínez-Zarzoso (2010), Table 1. 
conomics: The Open-Access, Open-Assessment E-Journal

developing country (10.6\%). This phenomenon is known as a "tariff bias" against developing countries.

In order to focus on the effect of trade barriers on imports from different countries, we estimate a separate regression for each of the 13 exporters included in the sample. ${ }^{15}$ We analyse the extent to which imports from developed and developing countries are deterred by tariffs and by trade facilitation barriers.

The results of estimating equation (2) for different countries are shown in Table 4. With respect to the trade facilitation variables, $97 \%$ of the estimated coefficients present the expected sign. The first part (a) of Table A.5 (Appendix I) shows the corresponding beta coefficients. On the one hand, regression results show that the highest beta coefficient in absolute terms is for income indicating that income is the most important determinant of bilateral trade flows in those countries, followed by distance in Brazil, Japan, Spain and United Kingdom. On the other hand, estimates for China, Japan and the United States exports show the largest beta coefficients for the number of documents and days needed to trade. Consequently, these countries would benefit the most from decreasing institutional trade barriers. Furthermore, beta coefficients show that improvements in technological achievement are also of greater importance for China, Japan and the United States than for the rest of countries. Trade facilitation variables are in general of greater importance than tariff barriers, except for Germany, and tariffs are non-significant for Brazil.

Additionally, the magnitude of the coefficient of the inland transport cost variable for exporters located far away from the main markets (China and Japan) is considerably higher than the average value obtained in Table 3. As the transport cost variable includes only internal transport costs, and we control for distance in the model, the question that arises is why products exported from China and Japan face greater elasticity with respect to internal transport costs. A possible explanation is that importers easily can substitute goods coming from those locations with goods coming from closer exporters with lower internal transport costs.

\footnotetext{
15 Regression results for Bolivia, Chile, Czech Republic, Ghana and South Africa are not reported because sample size was considerably reduced due to missing tariff data. Full results are available upon request from the authors.
} 


\section{Economics: The Open-Access, Open-Assessment E-Journal}

Table 4: The Effect of Policy and Institutional Trade Barriers (by Exporter)

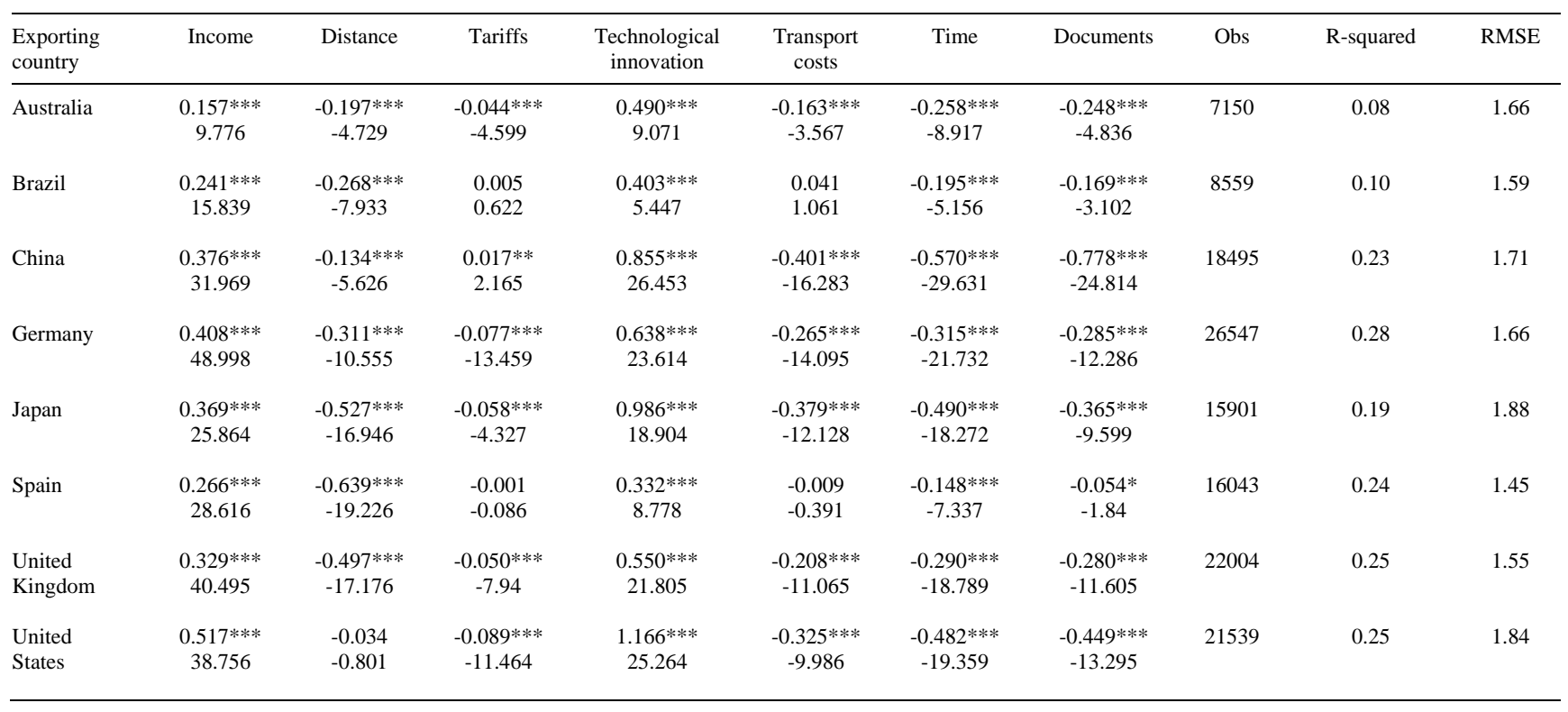

Notes: ***,**,* indicate significance at $1 \%, 5 \%$ and $10 \%$, respectively. The corresponding t-statistic is reported below each coefficient. All regressions include variables from Equation (2), the coefficients are not reported to save space. The dependent variable is the natural logarithm of exports in value (thousands of \$US) of commodity $\mathrm{k}$ from country $\mathrm{i}$ to $\mathrm{j}$. The estimation uses White's heteroskedasticity -consistent standard errors. Data is for the year 2000. Income, distance, tariffs, number of observations, R-squared and RMSE correspond to regression including technological innovation as a trade facilitation measure. 
Next, the effect of trade barriers and trade facilitation variables on trade for different sectors are analysed and compared. Two classifications are considered. Firstly, the model is estimated for differentiated, reference-priced and homogeneous goods according to the Rauch classification. High-technology goods, as defined in the OECD (2001) and Eurostat (1999) classifications are also considered as a separate category (see Márquez-Ramos, 2007). Secondly, the model is estimated for each of the sections of the SITC (Sections 0-9). ${ }^{16}$ Table 5 shows the main results and the second part (b) of Table A.5 (Appendix I) shows beta coefficients.

When Rauch's classification and high-technology sectors are considered, results show that the highest beta coefficient, in absolute terms, is for income (except for Section 1- Beverages and tobacco and 3 - Mineral fuels, lubricants and related materials). Trade facilitation improvements would benefit differentiated, reference-priced and high-technology products to a greater extent than homogeneous goods. This result is in line with the assumption that the search model developed by Rauch (1999) applies most strongly to differentiated products and most weakly to products traded on organised exchanges. Hence, trade facilitation variables should have the greatest effects on matching international buyers and sellers of differentiated products, and search costs should act as the greatest barrier to trade in differentiated products.

In relation to the second classification, the coefficient of tariffs is negative and significant and registers negative elasticities between -0.03 and -0.06 . According to the results obtained, the greatest beta coefficients for tariffs are found in "sensitive" products such as mineral fuels, lubricants and related materials (Section 3); and animal and vegetable oils, fats and waxes (Section 4). These results can be compared with those obtained by other authors. For example, Fink et al. (2005) also estimate a sectoral gravity equation using trade flows classified according to the Rauch classification. These authors find that the estimated coefficient for the tariff variable is not statistically different from zero in the case of differentiated goods, whereas it is negative and statistically significant in the case of reference-priced and homogeneous goods. Along the same lines, Tang (2006) analyses the factors that contribute to the growth of US imports in

16 See Table A.6 in Appendix I for a description of each section. 
Economics: The Open-Access, Open-Assessment E-Journal

Table 5: The Effect of Policy and Institutional Trade Barriers (by Sector)

\begin{tabular}{|c|c|c|c|c|c|c|c|c|}
\hline & Tariffs & $\begin{array}{l}\text { Technological } \\
\text { innovation }\end{array}$ & $\begin{array}{l}\text { Transport } \\
\text { costs }\end{array}$ & Time & Documents & Observations & R-squared & RMSE \\
\hline \multicolumn{9}{|l|}{ Rauch Classification } \\
\hline Referenced & $\begin{array}{l}-0.022 * * * \\
-5.079\end{array}$ & $\begin{array}{l}0.512 * * * \\
30.183\end{array}$ & $\begin{array}{l}0.030^{* *} \\
2.173\end{array}$ & $\begin{array}{l}-0.335 * * * \\
-34.874\end{array}$ & $\begin{array}{l}-0.428^{* * *} \\
-27.539\end{array}$ & 35283 & 0.21 & 1.60 \\
\hline Homogeneous & $\begin{array}{l}-0.048 * * * \\
-5.769\end{array}$ & $\begin{array}{l}0.027 \\
0.568\end{array}$ & $\begin{array}{l}0 \\
-0.006\end{array}$ & $\begin{array}{l}-0.089^{* * *} \\
-3.582\end{array}$ & $\begin{array}{l}0.007 \\
0.173\end{array}$ & 7454 & 0.08 & 1.93 \\
\hline \multicolumn{9}{|l|}{ Sections SITC 1-Digit level } \\
\hline Food and live animals & $\begin{array}{l}0.009 \\
1.157\end{array}$ & $\begin{array}{l}0.135^{* * *} \\
4.014\end{array}$ & $\begin{array}{l}-0.023 \\
-0.975\end{array}$ & $\begin{array}{l}-0.155^{* * *} \\
-9.414\end{array}$ & $\begin{array}{l}-0.232^{* * *} \\
-8.578\end{array}$ & 12005 & 0.14 & 1.69 \\
\hline Beverages and tobacco & $\begin{array}{l}-0.008 \\
-0.522\end{array}$ & $\begin{array}{l}0.434^{* * *} \\
4.636\end{array}$ & $\begin{array}{l}-0.035 \\
-0.546\end{array}$ & $\begin{array}{l}-0.260^{* * *} \\
-5.811\end{array}$ & $\begin{array}{l}-0.286^{* * *} \\
-3.871\end{array}$ & 1643 & 0.09 & 1.77 \\
\hline Animal and vegetable oils & $\begin{array}{l}-0.03 \\
-1.586\end{array}$ & $\begin{array}{l}-0.063 \\
-0.638\end{array}$ & $\begin{array}{l}0.255^{* * *} \\
3.385\end{array}$ & $\begin{array}{l}-0.087 \\
-1.606\end{array}$ & $\begin{array}{l}-0.063 \\
-0.77\end{array}$ & 1249 & 0.13 & 1.40 \\
\hline Chemicals and related & $\begin{array}{l}0.006 \\
0.806\end{array}$ & $\begin{array}{l}0.692 * * * \\
33.887\end{array}$ & $\begin{array}{l}0.110^{* * *} \\
6.513\end{array}$ & $\begin{array}{l}-0.456^{* * *} \\
-37.556\end{array}$ & $\begin{array}{l}-0.512^{* * *} \\
-26.019\end{array}$ & 22926 & 0.31 & 1.53 \\
\hline Manufactured goods & $\begin{array}{l}-0.031^{* * *} \\
-7.864\end{array}$ & $\begin{array}{l}0.414^{* * *} \\
27.829\end{array}$ & $\begin{array}{l}-0.021^{*} \\
-1.675\end{array}$ & $\begin{array}{l}-0.328^{* * *} \\
-38.632\end{array}$ & $\begin{array}{l}-0.487^{* * *} \\
-34.642\end{array}$ & 38786 & 0.24 & 1.54 \\
\hline
\end{tabular}




\section{Economics: The Open-Access, Open-Assessment E-Journal}

Table 5 continued

\begin{tabular}{|c|c|c|c|c|c|c|c|c|}
\hline & Tariffs & $\begin{array}{l}\text { Technological } \\
\text { innovation }\end{array}$ & $\begin{array}{l}\text { Transport } \\
\text { costs }\end{array}$ & Time & Documents & Observations & R-squared & RMSE \\
\hline \multicolumn{9}{|l|}{ Sections SITC 1-Digit level } \\
\hline Machinery and transport & $\begin{array}{l}0.032^{* * *} \\
6.339\end{array}$ & $\begin{array}{l}0.809 * * * \\
48.896\end{array}$ & $\begin{array}{l}-0.085^{* * *} \\
-5.91\end{array}$ & $\begin{array}{l}-0.537 * * * \\
-56.273\end{array}$ & $\begin{array}{l}-0.700^{* * *} \\
-43.895\end{array}$ & 40798 & 0.30 & 1.76 \\
\hline Miscell. Manufactures & $\begin{array}{l}0.008 \\
1.399\end{array}$ & $\begin{array}{l}0.432 * * * \\
19.939\end{array}$ & $\begin{array}{l}-0.302^{* * *} \\
-16.013\end{array}$ & $\begin{array}{l}-0.396 * * * \\
-32.54\end{array}$ & $\begin{array}{l}-0.651 * * * \\
-32.234\end{array}$ & 21070 & 0.27 & 1.68 \\
\hline Commodities N.E.C & $\begin{array}{l}-0.059 * * \\
-2.092\end{array}$ & $\begin{array}{l}0.986 * * * \\
4.335\end{array}$ & $\begin{array}{l}0.067 \\
0.362\end{array}$ & $\begin{array}{l}-0.416^{* * *} \\
-3.447\end{array}$ & $\begin{array}{l}-0.415^{* *} \\
-2.199\end{array}$ & 459 & 0.19 & 2.30 \\
\hline
\end{tabular}

Notes: $* * * * * *$ indicate significance at $1 \%, 5 \%$ and $10 \%$, respectively. The corresponding t-statistic is reported below each coefficient. All regressions include variables from Equation (2), the coefficients are not reported to save space. The dependent variable is the natural logarithm of exports in value (thousands of \$US) of commodity $\mathrm{k}$ from country i to j. The estimation uses White's heteroskedasticity -consistent standard errors. Data is for the year 2000. Tariffs, number of observations, R-squared and RMSE correspond to regression including technological innovation as a trade facilitation measure. 
conomics: The Open-Access, Open-Assessment E-Journal

differentiated, reference-priced and homogeneous goods. Although US tariffs on differentiated goods were reduced by $2.25 \%$ in the period $1975-2000$, this reduction explains only $0.2 \%$ of the growth in US imports of differentiated goods. Meanwhile, the contribution of decreasing tariff barriers to the growth of US imports is about $8 \%$ for reference-priced and $13.7 \%$ for homogeneous goods. Tariff barriers therefore play a more important role for trade in reference-priced and homogeneous goods, as when comparing across different regressions the obtained beta coefficients in tariff variables are higher in magnitude for homogeneous goods than for differentiated, referenced and high-technological goods.

In relation to trade facilitation variables, results show that improvements in service infrastructure (measured as countries' technological achievement), and reducing the number of days and documents required for trade are of greater importance than internal transport costs (which include all the official fees associated with completing the procedures to export or import goods), the highest beta coefficients for these variables are found in Chemicals and related products (Section 5) and Machinery and transport equipment (Section 7). Nonetheless, inland transport costs play an important role in the case of trade of goods included in Section 8.

\section{Conclusions and Policy Implications}

In this paper, the effect of reducing trade barriers is analysed and compared with the effect of improving trade facilitation using sectoral data, as disaggregation allows a more accurate analysis of policies for different products. Time, number of documents and cost of trade, as well as information technology achievements are used as proxies for trade facilitation, while tariffs are measured as the weighted average effectively applied tariffs for each country importing each product from the 13 exporters in the sample.

Overall, the main results indicate that trade facilitation variables are, in relative terms, more important than tariffs, and this result is also obtained for specific countries and sectors. The single-exporter regressions indicate that our model performs better for developed countries than for developing exporters, for which 
other factors, such as exchange rates, market access or infrastructures, could be the main determinants of exports.

The results for specific types of goods indicate that trade facilitation improvements would benefit trade in differentiated and high-technology sectors to a greater extent than trade in homogeneous goods, basically due to the different weight of fixed costs that both groups of products are assuming.

Important policy implications can be derived from this study. In relation to tariff barriers, it is widely recognised that trade policy is still a key issue in low and middle income countries today due to a number of factors. First, as the border is often the easiest point to levy taxes, revenue needs may be determining trade policy in developing countries. Second, the infant industry argument has determined trade policy in a number of developing countries after the Second World War. ${ }^{17}$ Third, the existence of influential lobby groups for government support may play a key role in the determination of trade protection in a number of "sensitive" products, as has recently been the case in the European Union after the re-establishment of Mercosur-EU trade negotiations within the Spanish rotating presidency of the EU. ${ }^{18}$ Finally, situations where tariffs rise along processing chains still prevail in a number of sectors which are mainly of export interest for developing countries, therefore limiting export growth and diversification in those countries. Therefore, tariff peaks ${ }^{19}$ and tariff escalation ${ }^{20}$ remain important issues

17 The infant industry argument supports the protection of domestic nascent industries as they do not have the economies of scale that their older competitors from other countries may have.

18 See "EU farmers led by France promise to lobby against concessions for Mercosur" in http://en.mercopress.com/2010/05/17/eu-farmers-led-by-france-promise-to-lobby-againstconcessions-for-mercosur.

19 Although most import tariffs are now quite low, particularly in developed countries, they remain high for a few products that governments consider to be "sensitive". These are "tariff peaks". Some affect exports from developing countries (see World Trade Organisation, 2010: “Understanding the WTO: Developing countries”).

20 Tariff escalation occurs when a country sets low tariffs on imported materials used by industry and higher tariffs on finished products to protect the goods produced by a particular manufacturing industry. If importing countries protect their industries in this way, they make it more difficult for countries producing raw materials to process and manufacture value-added products for export. Tariff escalation exists in both developed and developing countries, but particularly affects those low-income countries which are 
for developing countries. This paper finds that trade policy negotiation efforts should also focus on facilitating trade processes, which should be at the forefront of multilateral negotiations. Decreasing institutional barriers would lead to an increase in world trade, although this increase would not be the same in all countries, or for all sectors. According to the results obtained, exports of homogeneous and referenced goods, such as agricultural products, from developing countries would experience lower increases than exports of differentiated products, which would benefit developed countries to a greater extent.

Finally, recent research suggests that extending the gravity equation to multiple sectors leads to a different model specification, where bilateral trade at sectoral level might depend on sector-specific multilateral resistance terms (Anderson and Yotov, 2010). Indeed, the cross sectional variation of multilateral resistance across regions (analysed for Canadian provinces in Anderson and Yotov, 2010) and commodities could be large. The importance of investigating whether the one-sector approach suggested by Baier and Bergstrand (2009) is still applicable to multiple sectors and intra-national trade flows is unquestionable. Since this research focuses exclusively on the quantification and comparison of the effect of policy and institutional trade barriers on international trade flows, although multilateral resistance may matter for estimation, it is arguably more important to derive comparative statics, and we leave this issue for further research.

Acknowledgement Financial support from the Spanish Ministry of Science and Technology is gratefully acknowledged (ECO 2010-15863). This paper is based on Working Paper No. 514 prepared by the authors for the Working Paper Collection of Fundación de las Cajas de Ahorros (FUNCAS).

highly specialised in raw materials (see World Trade Organisation, 2010: "Understanding the WTO: Developing countries”). http://www.wto.org/. 
Cconomics: The Open-Access, Open-Assessment E-Journal

\section{APPENDIX I}

Figure A.1: Average Applied Tariff Rates (1981-2007)

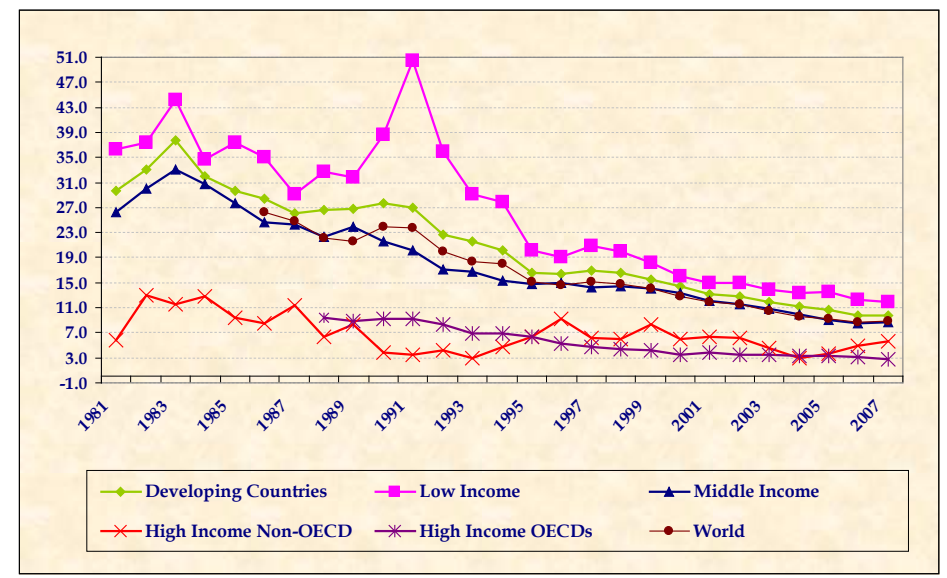

Source: The World Bank, Trade Research Division. ${ }^{21}$

21 "Trends in average applied tariff rates in developing and industrial countries, 19812007”. The data are compiled from UNCTAD, IMF, WTO, and country sources. Data on Trade and Import Barriers, The World Bank. 
Table A.1: List of Countries

Importing countries: Afghanistan, Albania, Algeria, Angola, Argentina, Armenia, Australia, Austria, Azerbaijan, Bahamas, Bahrain, Bangladesh, Barbados, Belarus, Belgium-Luxembourg, Belize, Benin, Bermuda, Bolivia, Bosnia Herzegovina, Brazil, Bulgaria, Burkina Faso, Burundi, Cambodia, Cameroon, Canada, Central African Republic, Chad, Chile, China, China Hong Kong SAR, China Macau SAR, Colombia, Congo, Costa Rica, Côte d'Ivoire, Croatia, Cuba, Cyprus, Czech Republic, Democratic Republic of the Congo, Denmark, Djibouti, Dominican Republic, Ecuador, Egypt, El Salvador, Equatorial Guinea, Estonia, Ethiopia, Fiji, Finland, France, Monaco, Gabon, Gambia, Georgia, Germany, Ghana, Gibraltar, Greece, Greenland, Guatemala, Guinea, Guinea Bissau, Guyana, Haiti, Honduras, Hungary, Iceland, Indonesia, Iran, Iraq, Ireland, Israel, Italy, Jamaica, Japan, Jordan, Kazakhstan, Kenya, Kiribati, Korea D P Republic, Korea Republic, Kuwait, Kyrgyzstan, Laos, Latvia, Lebanon, Liberia, Libya, Lithuania, Madagascar, Malawi, Malaysia, Mali, Malta, Mauritania, Mauritius, Mexico, Mongolia, Morocco, Mozambique, Myanmar, Nepal, Netherlands Antilles and Aruba, Netherlands, New Caledonia, New Zealand, Nicaragua, Niger, Nigeria, Norway, Oman, Pakistan, Panama, Papua New Guinea, Paraguay, Peru, Philippines, Poland, Portugal, Qatar, Republic of Moldova, Romania, Russia, Rwanda, Samoa, Saudi Arabia, Senegal, Seychelles, Sierra Leone, Singapore, Slovakia, Slovenia, Somalia, South Africa, Spain, Sri Lanka, St Kitts and Nevis, Sudan, Suriname, Sweden, Switzerland-Liechtenstein, Syria, The former Yugoslav Republic of Macedonia, Taiwan, Tajikistan, Tanzania, Thailand, Togo, Trinidad and Tobago, Tunisia, Turkey, Turkmenistan, United Kingdom, United States, Uganda, Ukraine, United Arab Emirates, Uruguay, Uzbekistan, Venezuela, Viet Nam, Yemen, Zambia, Zimbabwe.

Exporting countries: Australia, Bolivia, Brazil, Chile, China, Czech Republic, Germany, Ghana, Japan, South Africa, Spain, United Kingdom, and the United States. 
conomics: The Open-Access, Open-Assessment E-Journal

Table A.2: The Effect of Policy and Institutional Trade Barriers. Estimation with Country Fixed Effects

\begin{tabular}{|c|c|c|c|c|}
\hline & Model 1 & Model 2 & Model 3 & Model 4 \\
\hline \multirow[t]{2}{*}{ Distance } & $-0.417 * * *$ & $-0.455^{* * *}$ & $-0.455^{* * *}$ & $-0.455^{* * *}$ \\
\hline & -49.875 & -59.431 & -59.431 & -59.431 \\
\hline \multirow[t]{2}{*}{ Tariffs } & $-0.024 * * *$ & $-0.023 * * *$ & $-0.023 * * *$ & $-0.023 * * *$ \\
\hline & -10.868 & -11.323 & -11.323 & -11.323 \\
\hline \multirow[t]{2}{*}{ CAN } & $1.025^{* * *}$ & $1.233^{* * *}$ & $1.233^{* * *}$ & $1.233^{* * *}$ \\
\hline & 4.036 & 5.132 & 5.132 & 5.132 \\
\hline \multirow[t]{2}{*}{ MERC } & -0.091 & -0.079 & -0.079 & -0.079 \\
\hline & -1.464 & -1.31 & -1.31 & -1.31 \\
\hline \multirow[t]{2}{*}{ EU } & -0.024 & $-0.098 * * *$ & $-0.098 * * *$ & $-0.098^{* * *}$ \\
\hline & -0.646 & -2.785 & -2.785 & -2.785 \\
\hline \multirow[t]{2}{*}{ EMU } & $0.089 * * *$ & $0.087 * * *$ & $0.087 * * *$ & $0.087 * * *$ \\
\hline & 3.009 & 3.111 & 3.111 & 3.111 \\
\hline \multirow[t]{2}{*}{ ECOWAS } & . & $-1.100 * * *$ & $-1.100 * * *$ & $-1.100 * * *$ \\
\hline & . & -3.944 & -3.944 & -3.944 \\
\hline \multirow[t]{2}{*}{ CEFTA } & $0.436 * * *$ & $0.279 * * *$ & $0.279 * * *$ & $0.279 * * *$ \\
\hline & 9.166 & 6.328 & 6.328 & 6.328 \\
\hline \multirow[t]{2}{*}{ NAFTA } & $0.842 * * *$ & $0.891 * * *$ & $0.891 * * *$ & $0.891^{* * *}$ \\
\hline & 12.45 & 13.387 & 13.387 & 13.387 \\
\hline \multirow[t]{2}{*}{ Colony } & $0.170^{* * *}$ & $0.237 * * *$ & $0.237 * * *$ & $0.237 * * *$ \\
\hline & 8.436 & 12.427 & 12.427 & 12.427 \\
\hline \multirow[t]{2}{*}{ Language } & $0.198 * * *$ & $0.129 * * *$ & $0.129 * * *$ & $0.129 * * *$ \\
\hline & 10.97 & 7.789 & 7.789 & 7.789 \\
\hline \multirow[t]{2}{*}{ Contiguity } & $0.502 * * *$ & $0.398 * * *$ & $0.398 * * *$ & $0.398 * * *$ \\
\hline & 21.086 & 18.635 & 18.635 & 18.635 \\
\hline \multirow[t]{2}{*}{ TAI } & $0.815^{* * *}$ & & & \\
\hline & 11.642 & & & \\
\hline \multirow[t]{2}{*}{ Transport Costs } & & $-0.327 * *$ & & \\
\hline & & -2.119 & & \\
\hline \multirow[t]{2}{*}{ Time } & & & $-0.132 * * *$ & \\
\hline & & & -4.4 & \\
\hline \multirow[t]{2}{*}{ Documents } & & & & $-0.629 * * *$ \\
\hline & & & & -3.862 \\
\hline \multirow[t]{2}{*}{ Constant Term } & $8.610^{* * *}$ & $9.257^{* * *}$ & $5.635^{* * *}$ & $6.759 * * *$ \\
\hline & 30.428 & 4.399 & 30.173 & 10.383 \\
\hline R-squared & 0.262 & 0.271 & 0.271 & 0.271 \\
\hline Number of observations & 149885 & 187936 & 187936 & 187936 \\
\hline RMSE & 1.662816 & 1.64844 & 1.64844 & 1.64844 \\
\hline Country fixed effects & Yes & Yes & Yes & Yes \\
\hline
\end{tabular}

Notes: ***, **, * indicate significance at $1 \%, 5 \%$ and $10 \%$, respectively. The corresponding t-statistic is reported below each coefficient. The dependent variable is the natural logarithm of exports in value (thousands of \$US) of commodity k from country i to j. The estimation uses White's heteroskedasticity-consistent standard errors. Data is for the year 2000. 
Cconomics: The Open-Access, Open-Assessment E-Journal

Table A.3: Beta Coefficients

\begin{tabular}{|l|c|}
\hline Variables & Table 3 \\
\hline Income & $0.31^{* * *}(122.91)$ \\
\hline Distance & $-0.15^{* * *}(-45.59)$ \\
\hline Tariffs & $-0.04^{* * *}(-10.82)$ \\
\hline Technological innovation & $0.15^{* * *} \quad(63.64)$ \\
\hline Transport costs & $-0.01^{* * *} \quad(-6.82)$ \\
\hline Time & $-0.17^{* * *}(-78.97)$ \\
\hline Documents & $-0.13^{* * *}(-63.32)$ \\
\hline Easy to trade & $-0.15^{* * *}(-68.30)$ \\
\hline
\end{tabular}

Notes: $* * *, * *, *$ indicate significance at $1 \%, 5 \%$ and $10 \%$, respectively. T-statistics are given in brackets. The dependent variable is the natural logarithm of exports in value (thousands of \$US) of commodity $\mathrm{k}$ from country $\mathrm{i}$ to $\mathrm{j}$. The estimation uses White's heteroskedasticity-consistent standard errors. Data is for the year 2000. Income, distance and tariffs correspond to regression including technological innovation as a trade facilitation measure. 
conomics: The Open-Access, Open-Assessment E-Journal

Table A.4: Average Weighted Tariffs by Importer

\begin{tabular}{|c|c|c|c|c|c|c|c|}
\hline & \multicolumn{2}{|c|}{ Observations } & Mean & Std. Dev. & Observations & Mean & Std. Dev. \\
\hline Exporter & \multicolumn{4}{|c|}{ The importing country is developed } & \multicolumn{3}{|c|}{ The importing country is developing } \\
\hline Australia & \multicolumn{2}{|c|}{5725} & 3.84 & 7.86 & 2532 & 10.60 & 11.71 \\
\hline Bolivia & \multicolumn{2}{|c|}{224} & 5.64 & 11.83 & 93 & 12.57 & 5.46 \\
\hline Brazil & \multicolumn{2}{|c|}{6013} & 4.81 & 6.51 & 3806 & 10.79 & 8.59 \\
\hline Chile & \multicolumn{2}{|c|}{1677} & 6.87 & 9.10 & 1391 & 12.31 & 5.97 \\
\hline China & \multicolumn{2}{|c|}{13915} & 5.09 & 5.76 & 9717 & 15.40 & 8.83 \\
\hline Czech Republic & \multicolumn{2}{|c|}{2996} & 5.81 & 6.83 & 2208 & 10.33 & 10.72 \\
\hline Germany & \multicolumn{2}{|c|}{21380} & 3.74 & 7.27 & 13849 & 11.02 & 8.22 \\
\hline Ghana & \multicolumn{2}{|c|}{303} & 0.69 & 2.26 & 53 & 17.55 & 13.09 \\
\hline Japan & \multicolumn{2}{|c|}{11893} & 5.73 & 16.30 & 7365 & 13.99 & 10.34 \\
\hline South Africa & \multicolumn{2}{|c|}{4358} & 5.28 & 11.54 & 4052 & 12.41 & 8.51 \\
\hline Spain & \multicolumn{2}{|c|}{12691} & 3.75 & 6.54 & 6980 & 14.29 & 9.84 \\
\hline United Kingdom & \multicolumn{2}{|c|}{18659} & 3.71 & 10.03 & 9754 & 12.43 & 18.44 \\
\hline United States & \multicolumn{2}{|c|}{17320} & 5.44 & 21.38 & 7349 & 11.71 & 7.74 \\
\hline \multicolumn{5}{|c|}{ Both trading partners are developed } & & & \\
\hline Observations & Mean & \multicolumn{2}{|c|}{ Std. Dev. } & Equal to 0 & & & \\
\hline 96699 & 4.48 & \multicolumn{2}{|c|}{12.83} & $33.19 \%$ & & & \\
\hline \multicolumn{5}{|c|}{ One or both trading partners are developing } & & & \\
\hline Observations & Mean & & ev. & Equal to 0 & & & \\
\hline 94414 & 10.59 & & & $4.11 \%$ & & & \\
\hline
\end{tabular}




\section{Economics: The Open-Access, Open-Assessment E-Journal}

Table A.5: Beta Coefficients. Sensitivity Analysis

\begin{tabular}{|l|c|c|c|c|c|c|c|c|}
\cline { 2 - 8 } a) By exporting country & Australia & Brazil & China & Germany & Japan & Spain & United Kingdom & United States \\
\hline Income & 0.13 & 0.25 & 0.28 & 0.30 & 0.25 & 0.23 & 0.27 & 0.28 \\
\hline Distance & -0.11 & -0.16 & -0.06 & -0.11 & -0.22 & -0.20 & -0.18 & -0.01 \\
\hline Tariffs & -0.09 & 0.01 & 0.02 & -0.13 & -0.08 & -0.001 & -0.09 & -0.15 \\
\hline Technological Innovation & 0.11 & 0.09 & 0.20 & 0.13 & 0.19 & 0.07 & 0.13 & 0.18 \\
\hline Transport costs & -0.04 & 0.01 & -0.10 & -0.06 & -0.09 & -0.002 & -0.06 & -0.07 \\
\hline Time & -0.10 & -0.08 & -0.22 & -0.11 & -0.16 & -0.06 & -0.11 & -0.15 \\
\hline Documents & -0.07 & -0.05 & -0.20 & -0.07 & -0.09 & -0.01 & -0.08 & -0.10 \\
\hline
\end{tabular}

\begin{tabular}{|c|c|c|c|c|c|c|c|c|c|c|c|c|c|c|}
\hline \multirow[b]{2}{*}{ b) By sector } & \multirow[b]{2}{*}{ Diff } & \multirow[b]{2}{*}{ Ref } & \multirow[b]{2}{*}{ Hom } & \multirow[b]{2}{*}{ H.Tech } & \multirow[b]{2}{*}{ S.0 } & \multirow[b]{2}{*}{ S.1 } & \multirow[b]{2}{*}{ S.2 } & \multirow[b]{2}{*}{ S.3 } & \multirow[b]{2}{*}{ S.4 } & \multirow[b]{2}{*}{ S.5 } & \multirow[b]{2}{*}{ S.6 } & & & \multirow[b]{2}{*}{ S.9 } \\
\hline & & & & & & & & & & & & S.7 & S.8 & \\
\hline Income & 0.33 & 0.27 & 0.21 & 0.38 & 0.23 & 0.13 & 0.24 & 0.22 & 0.17 & 0.35 & 0.30 & 0.36 & 0.39 & 0.31 \\
\hline Distance & -0.15 & -0.15 & -0.07 & -0.18 & -0.08 & -0.05 & -0.05 & -0.23 & -0.01 & -0.19 & -0.18 & -0.18 & -0.16 & -0.06 \\
\hline Techn. Innov. & 0.17 & 0.15 & 0.01 & 0.25 & 0.04 & 0.13 & 0.04 & 0.11 & -0.02 & 0.20 & 0.13 & 0.21 & 0.12 & 0.20 \\
\hline Transport costs & -0.02 & 0.01 & -0.001 & -0.04 & -0.01 & -0.01 & 0.01 & -0.01 & 0.09 & 0.03 & -0.01 & -0.02 & -0.09 & 0.01 \\
\hline Documents & -0.16 & -0.12 & 0.001 & -0.19 & -0.07 & -0.08 & 0.01 & -0.08 & -0.02 & -0.14 & -0.14 & -0.17 & -0.17 & -0.09 \\
\hline
\end{tabular}


Conomics: The Open-Access, Open-Assessment E-Journal

Table A.6: Sectoral Classification

\begin{tabular}{|r|l|}
\hline Code & Description \\
\hline 0 & Food and live animals \\
\hline 1 & Beverages and tobacco \\
\hline 2 & Crude materials, inedible, except fuels \\
\hline 3 & Mineral fuels, lubricants and related materials \\
\hline 4 & Animal and vegetable oils, fats and waxes \\
\hline 5 & Chemicals and related products, n.e.s. \\
\hline 6 & Manufactured goods classified chiefly by material \\
\hline 7 & Machinery and transport equipment \\
\hline 8 & Miscellaneous manufactured articles \\
\hline 9 & Commodities and transactions not classified elsewhere in the SITC \\
\hline
\end{tabular}

Note: Standard International Trade Classification at one digit level. Source: United Nations Statistics Division. http://unstats.un.org. 
conomics: The Open-Access, Open-Assessment E-Journal

\section{APPENDIX II}

The Doing Business Dataset compiles the procedural requirements for exporting and importing a standardised cargo of goods. Every official procedure for exporting and importing goods is recorded (from the contractual agreement between the two parties to the delivery of goods) along with the time and cost necessary for completion. All documents required for the clearance of goods across the border are also recorded. For exporting goods, procedures range from packing the goods at the factory to their departure from the port of origin. For importing goods, procedures range from the vessel's arrival at the port of entry to the delivery of the cargo to the factory warehouse. Local freight forwarders, shipping lines, customs brokers and port officials provide information on required documents and costs, as well as the time for completing each procedure. To make the data comparable across countries, several assumptions regarding the business and the traded goods are made. The main assumptions refer to the business and types of goods traded. The business has to be located in the country's most populous city, and must have 200 employees or more. It is assumed to be a private, limited liability company that does not operate within an export processing zone, or an industrial estate with special export or import privileges. The business must be domestically owned with no foreign ownership and must export more than $10 \%$ of its sales.

The traded product must travel in a dry-cargo, 20-foot, full container load, not be hazardous, and not include military items. In addition, it must not require special conditions for transport, such as refrigeration, and must not require any special plant health or environmental safety standards other than accepted international standards. Finally, the product falls under the following Standard International Trade Classification (SITC) Revision categories: SITC 65 (textile yarn, fabrics and made-up articles); SITC 84 (articles of apparel and clothing accessories) or SITC 07 (coffee, tea, cocoa, spices and manufactures thereof). ${ }^{22}$

The inland transport cost is recorded as the fees levied on a 20-foot container in US dollars. All the fees associated with completing the procedures to export or

22 Martínez-Zarzoso and Márquez-Ramos (2008) estimate a gravity model using only exports for the 3 SITC product categories considered to collect data on trade facilitation variables. These authors obtain that the sign and significance of the coefficients on trade facilitation variables are similar to those found for the sample including all sectors. 
conomics: The Open-Access, Open-Assessment E-Journal

import goods are included. These, in turn, include costs of documents, administrative fees for customs clearance and technical control, terminal handling charges and inland transport. The cost measurement does not include tariffs or trade taxes. Only official costs are recorded.

A number of limitations should be mentioned. First, Doing Business indicators are not actual costs, but estimates provided often by consulting firms such as local freight forwarders, shipping lines, customs brokers and port officials, which are not actual traders, and hence capture de jure rather than de facto time and cost. ${ }^{23}$ Second, the standardized setting of a container shipped from the largest city via the major port may be appropriate for particular countries, but is not representative for countries whose trade goes by bulk carriers or for geographically large countries. Furthermore, Persson (2011) highlights that desirable trade facilitation measures should vary over time, and should be product-specific with bilateral variation across countries. Finally, Behar (2010) constructs country-level aggregates of trade facilitation measures from firm-level responses obtained from the Enterprise Surveys and compares them with the Doing Business indicators, the Logistics Performance Index and the Enabling Trade Index. His results show that correlations between the data sources are low. These findings raise the issue of which form of variation (within-country, inter-firm and between-country variation) is more informative and which data source is more reliable.

23 Therefore, Doing Business data does not allow, for example, differentiating costs depending on the size of the trading firm. 
conomics: The Open-Access, Open-Assessment E-Journal

\section{References}

Anderson, J. E. and E. van Wincoop (2003). Gravity with gravitas: A solution to the border puzzle. American Economic Review 93(1): 170-192.

http://ideas.repec.org/a/aea/aecrev/v93y2003i1p170-192.html

Anderson, J. E. and E. van Wincoop (2004). Trade costs. Journal of Economic Literature 42(3): 691-751.

http://ideas.repec.org/a/aea/jeclit/v42y2004i3p691-751.html

Anderson, J.E. and Y. Yotov (2010). The changing incidence of geography. American Economic Review 100(5): 2157-2186.

http://ideas.repec.org/a/aea/aecrev/v100y2010i5p2157-86.html

Baier, S. L. and J.H. Bergstrand (2001). The growth of world trade: Tariffs, transport costs, and income similarity. Journal of International Economics 53 (1): 1-27. http://ideas.repec.org/a/eee/inecon/v53y2001i1p1-27.html

Baier, S.L. and J.H. Bergstrand (2009). Bonus vetus OLS: A simple method for approximating international trade-cost effects using the gravity equation. Journal of International Economics 77: 77-85. http://ideas.repec.org/a/eee/inecon/v77y2009i1p77-85.html

Behar, A. (2010). Do managers and experts agree? A comparison of alternative sources of trade facilitation data. Economics Series Working Papers 503, University of Oxford, Department of Economics. http://ideas.repec.org/p/oxf/wpaper/503.html

Bergstrand, J.H., P. Egger, and M. Larch (2011). Gravity redux: Estimation of gravity-equation coefficients, elasticities of substitution, and general equilibrium comparative statics under asymmetric bilateral trade costs. Unpublished working paper, Available at:

http://www.nd.edu/ jbergstr/working_papers.html

Chen, N. (2004). Intra-national versus international trade in the European Union: Why do national borders matter? Journal of International Economics 63(1): 93-118. http://ideas.repec.org/a/eee/inecon/v63y2004i1p93-118.html

Cheng, I.-H. and H.J. Wall (2005). Controlling for heterogeneity in gravity models of trade and integration. Federal Reserve Bank of St. Louis, Review 87(1): 4963. http://ideas.repec.org/a/fip/fedlrv/y2005ijanp49-63nv.87no.1.html 
conomics: The Open-Access, Open-Assessment E-Journal

Cyrus, T.L. (2002). Income in the gravity model of bilateral trade: Does Endogeneity Matter? The International Trade Journal 16(2): 161-180. http://www.tandfonline.com/doi/abs/10.1080/08853900252901404

Decreux, I. and Fontagne, L. (2006). A quantitative assessment of the outcome of the Doha development agenda. CEPII, Working Paper No. 2006-10. http://www.cepii.fr/anglaisgraph/workpap/summaries/2006/wp06-10.htm

Dennis, A. (2006). The impact of regional trade agreements and trade facilitation in the Middle East and North Africa region. Policy Research Working Paper 3837, The World Bank, Washington, D.C. http://ideas.repec.org/p/wbk/wbrwps/3837.html

Djankov, S., C. Freund, and C.S. Pham (2006). Trading on time. Policy Research Working Paper 3909, The World Bank, Washington, D.C. http://ideas.repec.org/p/wbk/wbrwps/3909.html

Eichengreen, B. and D. Irwin (1998). The role of history in bilateral trade flows. In: J.A. Frankel, ed., The regionalization of the world economy. Chicago: University of Chicago Press.

Engman, M. (2005). The economic impact of trade facilitation. OECD Trade Policy Working Papers 21, OECD Trade Directorate, Paris.

http://ideas.repec.org/p/oec/traaab/21-en.html

Eurostat (1999). Répartition régionale de l'emploi dans les secteurs de Haute Technologie. Serie 'Statistiques en Bref'. Luxemburg.

Feenstra, R.C. (2004). Advanced international trade. Theory and evidence. Princeton University Press, Princeton.

Feenstra, R.C., R.E. Lipsey, H. Deng, A.C. Ma, and H. Mo (2005). World trade flows: 1962-2000. NBER Working Paper No. 11040, National Bureau of Economic Research, Cambridge, MA. http://www.nber.org/papers/w11040

Fink, C., A. Mattoo, and I.C. Neagu (2005). Assessing the impact of communication costs on international trade. Journal of International Economics 67(2): 428-445.

Freund, C.L. and D. Weinhold (2004). The effect of the Internet on international trade. Journal of International Economics 62(1): 171-189.

http://ideas.repec.org/a/eee/inecon/v62y2004i1p171-189.html 
conomics: The Open-Access, Open-Assessment E-Journal

Harrigan J. (1993). OECD imports and trade barriers in 1983. Journal of International Economics 35: 91-111.

http://ideas.repec.org/a/eee/inecon/v35y1993i1-2p91-111.html

Hummels, D. (2007). Transportation costs and international trade in the second era of globalization. Journal of Economic Perspectives 21(3): 131-154.

http://ideas.repec.org/a/aea/jecper/v21y2007i3p131-154.html

Kreinin, M.E. (1961). Effect of tariff changes on the prices and volume of imports. The American Economic Review 51(3): 310-324.

http://www.jstor.org/stable/1814161

Márquez Ramos, L. (2007). New determinants of bilateral trade: An empirical analysis for developed and developing countries. Doctoral Dissertation. Universitat Jaume I, Castellón de la Plana.

http://www.tesisenred.net/bitstream/handle/10803/10361/marquez.pdf?sequen $\mathrm{ce}=1$

Márquez-Ramos, L. and I. Martínez-Zarzoso (2010). The effect of technological innovation on international trade. A nonlinear approach. Economics: The Open-Access, Open-Assessment E-Journal, Vol. 4, 2010-11.

http://dx.doi.org/10.5018/economics-ejournal.ja.2010-11

Martínez-Zarzoso, I and L. Márquez-Ramos (2008). The effect of trade facilitation on sectoral trade. The B.E. Journal of Economic Analysis \& Policy 8(1) (Berkeley Electronic Press). http://www.bepress.com/bejeap/vol8/iss1/art42

Melitz, J. (2008). Language and foreign trade. European Economic Review 52(4): 667-699. http://ideas.repec.org/a/eee/eecrev/v52y2008i4p667-699.html

Nordas, E.P., E. Pinali, and N.G. Grosso (2006). Logistics and time as a trade barrier. OECD Trade Policy Working Papers 35, OECD Trade Directorate, Paris. http://ideas.repec.org/p/oec/traaab/35-en.html

OECD (2001). Classification des secteurs et des produits de haute technologie. OECD, Paris

OECD (2003). Quantitative Assessment of the Benefits of Trade Facilitation. TD/TC/WP31, OECD, Paris. 
conomics: The Open-Access, Open-Assessment E-Journal

Persson, M. (2007). Trade facilitation and the EU-ACP economic partnership agreements: Who has the most to gain? Working Papers 2007:8, Lund University, Department of Economics. http://ideas.repec.org/p/hhs/lunewp/2007_008.html

Persson, M. (2011). From trade preferences to trade facilitation: Taking stock of the issues. Economics Discussion Papers, No 2011-23, Kiel Institute for the World Economy.

http://www.economics-ejournal.org/economics/discussionpapers/2011-23

Pomfret, R. and P. Sourdin (2010). Trade facilitation and the measurement of trade costs. Journal of International Commerce, Economics and Policy 1(01): 145163. http://ideas.repec.org/a/wsi/jicepx/v01y2010i01p145-163.html

Rauch, J.E. (1999). Networks versus markets in international trade. Journal of International Economics 48(1): 7-35. http://ideas.repec.org/a/eee/inecon/v48y1999i1p7-35.html

Soete, L. (1987). The impact of technological innovation on international trade patterns: The evidence reconsidered. Research Policy 16 (2-4): 101-130. http://ideas.repec.org/a/eee/respol/v16y1987i2-4p101-130.html

Soloaga, I., J. Wilson, and A. Mejía (2006). Moving forward faster: Trade facilitation reform and Mexican competitiveness. World Bank Policy Research Working Paper No. 3953, The World Bank, Washington, D.C. http://econ.worldbank.org/external/default/main?pagePK=64165259\&theSite $\mathrm{PK}=469072 \&$ piPK=64165421\&menuPK=64166322\&entityID=000016406_2 0060622151914

Tang, L. (2006). What accounts for the growth of trade in differentiated goods: Economic causes or technological imperatives? Economics Letters 91: 204209. http://ideas.repec.org/a/eee/ecolet/v91y2006i2p204-209.html

UNCTAD (United Nations Conference on Trade and Development) (2001). Ecommerce and development report 2001. UNCTAD, Geneva. http://r0.unctad.org/ecommerce/docs/edr01_en.htm

UNDP (United Nations Development Programme) (2001). Human development report. New York: Oxford University Press. 
Cconomics: The Open-Access, Open-Assessment E-Journal

Vernon, R. (1970). The technology factor in international trade. National Bureau of Economic Research, Cambridge, MA.

http://ideas.repec.org/b/nbr/nberbk/vern70-1.html

Wilson, J.S., C.L. Mann, and T. Otsuki (2003). Trade facilitation and economic development: A new approach to quantifying the impact. The World Bank Economic Review 17(3): 367-389.

http://ideas.repec.org/a/oup/wbecrv/v17y2003i3p367-389.html

Wilson, J.S., C.L. Mann, and T. Otsuki (2005). Assessing the benefits of trade facilitation: A global perspective. World Economy 28(6): 841-871. http://ideas.repec.org/a/bla/worlde/v28y2005i6p841-871.html

World Bank (2005). World development indicators. The World Bank, Washington, D.C.

World Bank (2006). Doing business. Washington, D.C. http://www.doingbusiness.org/ 


\section{Conomics}

The Open-Access, Open-Assessment E-Journal

Please note:

You are most sincerely encouraged to participate in the open assessment of this article. You can do so by either recommending the article or by posting your comments.

Please go to:

http://dx.doi.org/10.5018/economics-ejournal.ja.2012-11

The Editor 